\title{
Carboxylation of Unprotected Indole Derivatives with Carbon Dioxide
}<smiles></smiles>

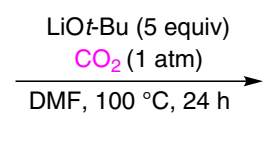

(1 equiv)

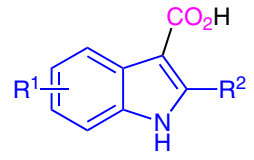

up to $97 \%$ yield

$$
\begin{aligned}
& \mathrm{R}^{1}=\mathrm{H}, \mathrm{Me}, \mathrm{OH}, \mathrm{OMe}, \mathrm{OBn}, \mathrm{CN}, \mathrm{F}, \mathrm{Br} \\
& \mathrm{R}^{2}=\mathrm{H}, \mathrm{Me}, \mathrm{Ph}
\end{aligned}
$$<smiles>CC(=O)OC(=O)OC(=O)c1c[nH]c2ccccc12</smiles>

95\% yield<smiles>O=C(O)c1c[nH]c2cccc(O)c12</smiles>

$83 \%$ yield<smiles>O=C(O)c1c[nH]c2ccc(Br)cc12</smiles>

96\% yield<smiles>COc1ccc2[nH]cc(C(=O)O)c2c1</smiles>

92\% yield<smiles>O=C(O)c1c[nH]c2c(Br)cccc12</smiles>

$88 \%$ yield<smiles>O=C(O)c1c[nH]c2ccc(F)cc12</smiles>

94\% yield<smiles>N#Cc1ccc2[nH]cc(C(=O)O)c2c1</smiles>

$90 \%$ yield<smiles>Cc1[nH]c2ccccc2c1C(=O)O</smiles>

$80 \%$ yield<smiles>O=C(O)c1c(-c2ccccc2)[nH]c2ccccc12</smiles>

$31 \%$ yield
Significance: A practical and straight-forward method for the preparation of indole-3-carboxylic acids has been reported. Deprotonation with $\mathrm{LiOt}$-Bu under an atmospheric pressure of carbon dioxide furnishes a variety of indole-3-carboxylic acids in high yield.
Comment: The described reaction is very versatile since it tolerates various functional groups and has therefore a broad substrate scope. According to the authors, the large excess of LiOt-Bu suppresses the undesired decarboxylation side reaction. 